\title{
Technical School in Toronto: Growing up in the Trades during the Second World War
}

\author{
John Allison
}

Nipissing University

\begin{abstract}
This article examines technical education in Toronto, Canada during the Second World War. Research on this topic reveals that there were enhanced links and patterns of interactions between the Toronto schools and the Canadian Armed Forces during the war. In particular, it was found that the war effort had a profound effect on technical education in Toronto because it strengthened links between the military and technical secondary schools, changed the curriculum and the school calendar, and helped attract technical students towards work in the armed forces and industry. The author examined these questions using primary sources from Toronto school archives and other City of Toronto archives.
\end{abstract}

RÉSUMÉ

Cet article s'intéresse à l'enseignement technique à Toronto (Canada) pendant la Deuxième Guerre mondiale. Cette recherche révèle qu'il y a eu des relations étroites et des modèles d'interactions entre les écoles torontoises et les Forces armées canadiennes durant la guerre. Entre autres, on a découvert que l'effort de guerre a eu des répercussions profondes sur l'enseignement spécialisé à Toronto. Il y a eu des rapprochements entre les militaires et les écoles techniques secondaires, on a modifié les programmes d'études et le calendrier scolaires et on a stimulé l'intérêt des élèves pour le travail dans l'armée et l'industrie. Cette recherche s'appuie sur des sources primaires provenant des archives des écoles torontoises et de la ville de Toronto.

\section{Introduction $^{*}$}

The Second World War stimulated the West to mobilize onto a wartime footing. Canada was no exception. Indeed, the focus on the war extended to Canadian schools. This paper will examine the wartime period, focusing on technical education. Technical secondary schools in the Toronto School Board make an excellent case study for this purpose, particularly Central Technical School. ${ }^{1}$ This school's history

\footnotetext{
* An earlier version of this paper was presented at the International Standing Conference for the History of Education (ISCHE) 36 conference held in London, UK, in 2014.
} 
is well documented and clearly shows the various impacts of the war. This paper will attempt to answer the following questions:

- In what ways did promotion of this war impact technical education in Toronto?

- To what extent did technical education in Toronto rely on military support?

- Were curriculum goals changed during the war as a result of one of Canada's largest cities being on a wartime footing?

- What were the impacts on students in technical education programs? To what degree were they pulled towards the "military trades," joining the military, or becoming involved in the war industry when they finished or left school?

The research for this paper was conducted at the Toronto District School Board Archives. ${ }^{2}$ Documentation at the City of Toronto Archives was also examined. ${ }^{3}$ Primary sources such as newspapers and diaries were consulted, and, in addition, an extensive analysis of secondary sources on the history of education in Toronto and the history of military education in Toronto was undertaken during the development of this paper.

Outside the scope of this paper is the degree to which technical education meant different things to different groups in Canada during wartime. For example, although First Nations people played a significant role in Canada's war effort, as Scott Sheffield documents, their history, insofar as it relates to technical education, will not be considered here. ${ }^{4}$ Similarly, the struggles of newly naturalized immigrants or immigrants of longer standing as expressed through their schooling are not addressed. ${ }^{5}$ The other significant topic that is not investigated in detail is the development of the politics of technical education across successive provincial governments and what changes in those provincial governments meant for technical education. ${ }^{6}$

\section{Definitions, and the Literature on Technical Education in Canada}

Before any further discussion of technical education begins, definitions of the key terms should be explored. This section will examine definitions of two key terms: "wartime footing" and "technical education."

Since the premise of this paper rests on understanding the term "wartime footing," it is important to fully explain its meaning in the context of the Second World War. In its most basic sense, wartime footing refers to a state in which a nation has successfully mobilized or organized for war. Mobilization is the initiation of this process, whereas the "garrison state" described in Lasswell's 1941 article tentatively sketched out what a new world and its states might look like if this condition were

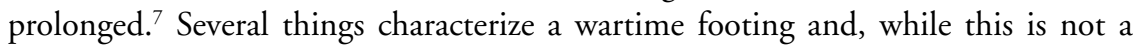
comprehensive list, it imparts a general sense of the term: total mobilization of the apparatus of government, ${ }^{8}$ the population, ${ }^{9}$ the economy, ${ }^{10}$ and the military ${ }^{11}$ to prepare for and sustain a war effort; state control and the refocusing of industry 
onto wartime production; ${ }^{12}$ and a realignment of society's aims towards winning the war. ${ }^{13}$ Finally, as will be shown, being on a wartime footing also relates to education, since school curricula and schedules also revolved around the war effort. Being on a wartime footing was not without its problems, particularly in the area of human resources. Stevenson documents this extensively in his 2001 work on the National Selective Service (NSS) in Canada. ${ }^{14}$

Turning now to defining technical education in Canada, note that this term has been confused and misused to represent other types of education. The distinction between "technical" and "vocational" education is fuzzy in the minds of many. Further to this, there are associated issues of class, gender, ethnicity, and discrimination. Each of these issues can be intertwined with the question of technical education. Added to this as an overarching layer is the issue of Canadian federalism and the question of who has responsibility for industry, the trades, apprenticeships, and naturally, technical education. The jurisdictional question has been highly contested from Confederation onwards, as will shortly become clear.

For some Canadian educators, administrators, and scholars of the twentieth century, however, the definition of technical education was highly prescribed. It also came with a long pedigree. Ian Dowbiggin's entry for Superintendent John Seath in the Dictionary of Canadian Biography provides us with a good starting point for this definition. ${ }^{15}$ Seath was the father of technical education in Ontario. From the $1860 \mathrm{~s}$ through to 1919 , he dominated this field. Seath studied the nature of technical and vocational education in Europe and the United States in order to further the field in Ontario. ${ }^{16}$ His studies and travels laid the groundwork for further efforts by government to define technical education through legislation. ${ }^{17}$ The interaction between the federal government and the provinces with regard to technical education has been documented elsewhere, in Turco's work. ${ }^{18}$ Concurrently with Seath's efforts, the federal government established the Royal Commission on Industrial Training and Technical Education in $1910 .{ }^{19}$ This commission tried to distinguish between technical and industrial education - the former being education of a more theoretical nature for those managing industries, the latter a general education for students who would enter the trades, with an emphasis on the practical. ${ }^{20}$ Formulating definitions was also important to those who drafted technical and vocational legislation, witness the federal Technical Education Act, 1919: "Technical education means and includes any form of vocational, technical or industrial education or instruction approved by agreement between the minister and the Government of any province as being necessary or desirable in aid of promoting industry and the mechanical trades and to increase the earning capacity, efficiency and productive power of those employed therein." ${ }^{21}$ In much of the period up to and including the Second World War, such definitions formed the bedrock of educational initiatives in technical education.

In a 1963 article, A. J. Peters, a noted British scholar of technical education, embraces all aspects of it in his definition. He first characterizes it as "education for artisans." A second definition of technical education later emerges: "general education for technical and commercial occupations." ${ }^{22}$ The term was defined differently again in the late nineteenth century, as emerges from Peter's study of the Report Relative to 
Technical Education of the UK Schools Inquiry Commission of $1867 .{ }^{23}$ Thus a third definition emerges: "separate schools for technical occupations." For the purposes of this paper, this definition will be used. Subsequently, yet another definition of the term became popular in elementary schools: "general education for children with certain aptitudes." ${ }^{24}$ Lastly, Peters notes, technical education became "general education for all in an era of technological change." 25 Peters concludes — and this is significant for this study — by arguing that four of the different definitions of technical education were still in use at the time he wrote his article. The degree to which they were applied in schools depended in large part on economic changes that prevailed and how different segments of society viewed the role of technical education. Gary McCulloch addressed this again in his article on the Technical Vocational Education Initiative of the 1980s, and Steve Jordan more recently with his 1996 doctoral thesis. ${ }^{26}$

The treatment of the Canadian history of technical education also provides a good rationale for further research into this topic. ${ }^{27}$ While the subject does not have a wellmarked place in recent historiographical analyses of the history of Canadian education, there is nevertheless some good coverage of this issue by Canadian historians. ${ }^{28}$ In looking at the nineteenth century, Suzanne Zeller builds on the work of several historians in examining the question from the perspective of Victorian sensibilities. ${ }^{29}$ Zeller asserts that technical education had a tortuous past in Canada: "[Canadian] policymakers never decisively embraced technical education as indispensible." 30 She goes on to argue that the scientization of technical education stoked conflicts over limited school resources in the nineteenth century. ${ }^{31}$ Zeller exhaustively documents the development of technical education from the Victorian era onward. ${ }^{32}$ Curtis, Livingstone, and Smaller, for their part, examine technical education in the context of educational inequity in Ontario. In their 1992 book on school streaming in Ontario, technical education was seen by organized labour in the nineteenth century as the route to economic security. ${ }^{33}$ Robert Gidney, Wyn Millar, and Alison Taylor further this analysis of technical education in Ontario. Gidney and Millar extensively examine the development of secondary schools in the province. ${ }^{34}$ They underline the distinctions between different types of technical education evident in the remarks made by the principal of a school of practical science in 1891: "technical education was of two types; manual training and theoretical and scientific training. One direction led to the trades and the other to higher education." ${ }^{5}$ Taylor, for her part, connects vocational and technical education to the reduction of youth crime among 1860s Ontario youth. ${ }^{36}$ Lyons, Randhawa, and Paulson provide an overview of the discussion of technical education in Canada and advance it to contemporary times. ${ }^{37}$ Lyons et al., and others, situate the start of technical education in Canada in the movement to establish grammar schools and collegiates in the nineteenth century. ${ }^{38}$ The distinction between collegiate institutes and high schools may not be readily apparent to many today, however, in that era, it was much more finely drawn and well established. ${ }^{39}$ Robert Stamp, in his treatment of technical schools, argues that much of the impetus for the creation of these schools came from business and commerce. By the latter part of the nineteenth century, the need for a trained technical workforce had become acute. ${ }^{40}$ Highly skilled technical labour was in high demand by the 
1890s. As Stamp notes as well, there was ongoing disagreement about who should provide technical education. ${ }^{41}$ The Canadian Manufacturers Association, the Trades and Labour Congress, and the Dominion Board of Trade all placed pressure on the federal government. ${ }^{42}$ Many felt that industry and provincial governments were doing a poor job of administering technical education, and that consequently, it should be under the jurisdiction of the federal government. ${ }^{43}$ The push for federal control over technical education continued into the 1910s with the efforts of Guelph, Ontario lawyer and Member of Parliament, Hugh Guthrie, as McIntyre documents. ${ }^{44}$ The issue was further addressed in 1910 with the establishment of a Royal Commission on the subject and with its subsequent report issued in 1913. Again in 1919, these efforts bore fruit with the passage of the Technical Education Act. ${ }^{45}$ The struggle over control of technical education and the degree to which industry plays a directive role is a debate that has continued to the present day. ${ }^{46}$

Sharman picks up this strand of the literature, examining the development of the Toronto Technical School in the years between 1891 and $1904 .{ }^{47}$ She argues that there are three approaches we can take when examining the history of technical education in Canada. ${ }^{48}$ In the first approach, the overarching structures of the system are examined; the second investigates the intersection between technical education, class, and gender. The final approach deals with the microanalysis of particular schools and their day-to-day functioning. ${ }^{49}$ Sharman and Glassford also do a comparative analysis of schools in Toronto and Windsor in terms of the similarities and differences in their development. ${ }^{50}$ Stamp, among others, notably Goodson and Dowbiggin, also looks at high schools from the 1900s through the 1920s and 1930s. ${ }^{51}$ Stamp notes one challenge that industry posed; companies accepted the graduates of only a few technical schools. For example, the Ford Motor Company only accepted graduates from the Windsor-Walkerville Technical School. ${ }^{52}$ Radforth and Sangster look at the aspirations of workers themselves; technical education was just a beginning, and they needed to have greater aspirations beyond this to continue to a liberal education. ${ }^{53}$ Smaller looks at vocational education in Toronto and notes that technical education facilities in northern Toronto were overbuilt in the $1920 \mathrm{~s} .{ }^{54}$ Goodson and Anstead, in their examination of Beal Technical School in London, Ontario between the 1920s and the 1940s, also give the reader a sense of the origins and development of technical education in Ontario centres outside Toronto. ${ }^{55}$ Elsewhere, Rebecca Coulter's work on the Canadian Youth Commission (1940-1948) and the nature of vocational education adds another dimension to this discussion as well. ${ }^{56}$ More recently, Freeman looked at the ABC vocational school from the 1960s to the early twenty-first century, once again demarcating the different streams of technical education in Ontario, one vocational and the other university- and college-bound. ${ }^{57}$

The Canadian literature clearly shows that technical education has been well analyzed on some levels. Despite this, there has not been much analysis of technical education in times of war in Canada. Moreover, the interrelationships among civic and military authorities and educational structures during wartime are not well understood. How military education is intertwined with the efforts of the school system is also not well documented. These gaps in the literature provide the rationale for 
further research, a need underlined by the lack of analysis of education generally in Ontario during wartime. Equally significant, at a more detailed level, is the limited treatment of Toronto's technical education history during the Second World War and its place in the broader history of technical education. It is to this past, with the hope of filling some of these gaps in the historical literature, that this discussion now turns.

\section{Tooling for War: The City of Toronto and Military Purposes}

Following the start of the war, it became clear that the purposes of technical education in Toronto were going to change. The war provided the context and opportunity in which links between schools and the armed forces, many of them already existing in the pre-war period, were radically expanded. The changing context can be seen at several levels, in terms of the schools themselves and the Toronto Board of Education, in terms of society in general, and in terms of the impact of federal legislation on the city. The war did much to draw Toronto and the Canadian armed forces closer together in the field of education.

From the opening days of the Second World War onward, military conflict provided an opportunity for deepening the connection between technical education and military services in Toronto. On September 7, 1939, six days after Canada declared war on the Third Reich, under Communications, Item 158, the Toronto Board of Education acknowledged receipt of a letter from the Department of National Defence that stated:

From the Department of National Defence requesting that the Central Technical School building and all its existing equipment, together with such members of the instructional and administrative staff as would be required to carry out the approved syllabus of training laid down by the Royal Canadian Air Force, be made available for the exclusive use of the Air Force, for the training of newly enlisted airmen who require training in a trade. ${ }^{58}$

The Board of Education responded positively to this request and the stage was set for the air force to come into Central Technical School..$^{59}$ Another immediate instance of close co-operation between Central Technical School and the Armed Forces was the secondment of a teacher from the school to the Lorne Scots Regiment in Brampton to teach army cooks for a period of three weeks in the fall of $1939 .{ }^{60}$

Toronto in wartime was scary for some, exciting for others, and generally moved to a different rhythm. ${ }^{61}$ Once war was declared in September 1939, new norms became the reality. The German blitzkrieg or "lightning war" conducted in Poland (although primarily as "proof of concept," as Frieser notes ${ }^{62}$ ) in early fall 1939 and later with great success in France in spring 1940 gave the Canadian government pause. The Wehrmacht and the Nazi war machine were highly mechanized and technologically almost a generation ahead of Canadian military hardware. Moreover, German industrial capacity had been rebuilt in the period after 1933. Furthermore, with France overrun and the devastation of the Battle of Britain in summer 1940, the implication 
was that the industrial burden would fall more heavily on the North American states, which were generally unprepared for war. ${ }^{63}$ Consequently, industrial production in Toronto ramped up as new factories were opened and brought up to speed. ${ }^{64}$

Change was evident in other ways in Toronto. The Canadian National Exhibition (CNE) was transformed from exhibition grounds to an armed military camp. ${ }^{65}$ Life in the city also started to change. The introduction of rotating blackouts marked the end of freely available electrical power. ${ }^{66}$ The needs of the industrial machine in Toronto were becoming more and more acute. ${ }^{67}$

As the war effort accelerated through 1941, another new wartime and military reality characterized Toronto. Manufacturing and industry became insatiable in their demands for materials, energy, and notably, labour. Bloomfield notes that the demand for labour after the start of the war multiplied. The size of the Canadian military between March 1939 and December 1943 also rose, from 900 to 739,000 members. ${ }^{68}$

Toronto also became the site for the enactment of federal policies supporting the expansion of industry and the military, which in turn impacted technical education. Several laws were enacted at this time. Fluxgold chronicles the passage of the Youth Training Act in 1939, the War Measures Act in 1940, and the War Emergency Training Program in 1940. ${ }^{69}$ Among the acts put in place in the early war years, the War Measures Act was the most significant because it overrode, as Fluxgold notes, "the provision in the Youth Training Act [1939] which prohibited the federal government from initiating programs and which specified that costs must be shared." ${ }^{\prime 0}$ With one stroke of the pen, the federal government took over technical education and labour matters for the duration of the war. ${ }^{71}$

\section{A Technical Course of Study:}

\section{A Twenty-Four Hour School Day and Curricular Change}

Curricular change was continual during the Second World War, impacting schooling in a variety of ways. Key among the changes were alterations to the school day and changes to courses of study. In 1942, the earlier Vocational Training Act was superseded by a new act entitled the Vocation Training Coordination Act. ${ }^{72}$ One of the key changes that resulted from this was the adoption of a new timetable and a new opening schedule. As Fluxgold notes, schools were now open continuously, running twenty-four hours a day:

The war emergency training program provided a large number of badly needed skilled workmen in a short period of time. In Ontario, many schools were in operation for 24 hours a day, training persons for specific jobs. Previously, vocational and technical training in the province had not been specifically joboriented: rather, it had been designed to give a student the general framework from which he might choose his specialty. The Minister of Education reported that it was "the first time in their history [that] vocational schools of the Province had been called upon to play a direct and important part in 
training men and women industrial workers and ... technical personnel." The war emergency training program also demonstrated the capabilities of the school to a critical industrial community. Industry had complained because the schools were not producing graduates who could move directly into the plant. The Minister of Education reported that "The war has brought the vocational school closer to industry than ever before. Many industrialists have learned for the first time that the schools are ready to function in the training of employees in a way which they had not previously believed possible. They have discovered that competent instructors with a broad background of trade experience are available to assist them in their problems."73

Around the clock schooling served three main groups, as discussed on the Central Technical School's website:

During the Second World War, Central Tech's excellent facilities were put to good use. The school was operated 24 hours a day. The day students attended from nine to three-thirty and from four p.m. to seven-thirty a.m. emergency classes were in progress. These classes were under the supervision of the Royal Canadian Air Force, Army and Navy. They involved marching drills, wireless operating, aircraft mechanics, tank repair and related subjects. Central Tech had the great honour of not only helping the community but the whole country. ${ }^{74}$

The war thus markedly changed the pace in Toronto's schools. ${ }^{75}$

In addition to changing the nature of the school day, the Second World War had an impact on curriculum in schools where technical education was a priority. It is important to first consider some of the broader trends in curriculum in Canada during the mid-twentieth century and wartime. The context for war and curricular change set the stage for the period to come. At a broad level, Christou, in his recent analysis of trends in Canadian education, speaks to the battle that took place in the interwar years with regard to progressivism and more traditional forms of education in Canada. ${ }^{76} \mathrm{He}$ supports the idea put forward by Robert Patterson that this era was a tumultuous period and that curriculum reform was the norm rather than the exception. ${ }^{77}$ Tomkins, for his part, argues that Canadian curricula were an amalgam of other international curricula and that after the Second World War ended, they became considerably more American in focus.

In addition to tumult and nascent Americanization, wartime brought with it general changes in the curriculum to focus more fully on building leadership, teamwork skills, and support for the war effort rather than a progressive curriculum. The latter, in the eyes of some, notably Ontario Premier George Drew, resulted in students with a propensity for delinquency. ${ }^{78}$ Instead, according to his and others' view, students should be keen to focus on the war, shoulder responsibility, and undertake the task at hand. This model student is to some extent present in student writing in wartime editions of the Central Technical School yearbook, the Vulcan. ${ }^{79}$ Additionally, as Millar 
and Keshen note, patriotism was inserted into most lessons in elementary and secondary schools.$^{80}$ Furthermore, students at all schools, regardless of their views, were required to help scrounge scrap metal, correspond with serving soldiers, whether through letters or care-packages, participate in the Farmerettes (a brigade of female students and teachers who supplied farm labour to replace men who had gone to war), and raise money in any way they could. ${ }^{81}$ At the same time, in some of their secondary history classrooms, Ontario students were exposed to a less jingoistic view of the war, a view that chronicled its defeats, its battles, and the origins of Nazism. ${ }^{82}$ In Verdun, Quebec, some students, like their counterparts in Toronto, wrote Britishthemed essays, as Durflinger notes. ${ }^{83}$ Teachers were encouraged to embed the war in all subjects. ${ }^{84}$ But while there was some change in elementary and general secondary school curricula with the outbreak of war, can the same be said of the secondary technical curriculum?

With the onset of the Second World War in 1939, there was no drastic change in terms of the base curriculum of Toronto's technical schools - that is to say, what subjects were taught. An examination of course calendars and yearbooks of the technical schools illuminate this. ${ }^{85}$ Throughout the war years, the standard offerings included Applied Electricity, Motor Mechanics, and Woodwork, among other subjects. ${ }^{86}$ What did change, however, was the degree to which students chose some courses over others. Many felt that training in the technical fields closely linked to the military service was a surer route to employment in the Armed Forces or in a closely allied industry. ${ }^{87}$ This idea was also reinforced in the Vulcan, Central Technical School's yearbook:

\begin{abstract}
Although Aircraft Drafting is taught as a supplementary, but not necessary subject in the aircraft course, without actually being designed to turn out draftsmen, it is interesting to note that many of the graduates of this course, have secured positions in the drafting departments of various aircraft companies, not only in Canada, but also in England and intend to make drafting their life's work. ${ }^{88}$
\end{abstract}

The curriculum of technical schools, particularly Central Technical School, was also shaped by the demand of students to take aeronautical studies, the Aircraft Course. ${ }^{89}$ Finally, there was an increasing focus on applied mathematics as the handmaiden of the technical and aeronautical fields. ${ }^{90}$ Some curricular change then was a key impact the war had on technical education. War also pulled students towards careers they would have not previously considered, both military and industrial.

\title{
From School to Service: Pulled into Military and Industrial Service by Machines
}

The environment in which Canadian technical education operated in the Second World War was one of advancing technological change. While the armed forces of the West (and the Axis) were happy to receive new equipment, they simultaneously needed a technologically knowledgeable force to run it. The development of technical education went hand-in-hand with changes in military education. This also 
happened concurrently with such things as the establishment of a culture of professional aviation in Canada, as Matthew Chapman notes. ${ }^{91}$ The Second World War also resulted in changing criteria applied to candidates who wished to become an officer in the Canadian Army, as Hayes notes. ${ }^{92}$ The value of education for the officer corps was increasingly apparent as the rate of technological change continued to accelerate and as armies needed technologically sophisticated officers more than ever.

There were several categories of individuals who were "pulled into the war:" students at school, cadets, and adult men and women as labourers. Among adults, there was an additional category, those who were upgrading their skills. For many, particularly as the war continued, the pull towards military service started in elementary school with increasingly patriotic messages being conveyed to students throughout the junior and intermediate grades. ${ }^{93}$

If one looks first at students, by the time they entered secondary school, the drumbeat of war-related messages had become relentless. War pulled students either towards enlisting in the armed forces or towards wartime industries. ${ }^{94}$ Central to technical education in the war were programs that encouraged students to complete technical training in school that served the needs of war. As Johnston notes, the pressure for technical students to engage with war-related subjects came from several different sources:

Moreover, technical school students benefited as early as 1940 from special war emergency classes that trained them in such vital crafts as instrument making and emergency aircraft work, and in the process opened up opportunities for their productive employment in war industries. A related Youth Training Program instructed students in the basics of drafting, welding, machine shop practice, and pattern making, which paved the way for their ready absorption into the wartime work force. ${ }^{95}$

Technical training was not only in high demand to build war-related material, but also to run it. Edwards, in his Maclean's article profiling technical education, states that in January 1942, Central Technical School had 5,083 regular students enrolled in day and evening classes. This number was supplemented by the 1,135 students taking nighttime classes. ${ }^{96}$ Additionally, Johnston describes the ever-present Air Force, Navy, and Army personnel in the schools. They were almost ubiquitous until the Toronto School Board intervened in 1943, concerned that schools were simply becoming recruiting centres. ${ }^{97}$ The tension around the issue of cadets and cadet recruiting was, for many, a sensitive one. Some felt that it was inappropriate in a school setting, while for others, enlisting students as cadets became a full-time preoccupation and patriotic obligation as the war effort accelerated. ${ }^{98}$

In turning to military cadets, the literature about cadets and their relationship to education springs from several sources. ${ }^{99}$ Notably, Moss considers the earlier history of cadets with his work on militarism in the late nineteenth century in Ontario. ${ }^{100}$ In spring 1939, the Canadian Cadet Association passed a resolution that favoured re-introducing cadet training in secondary schools. The Toronto Board of Education 
declared in 1939 that service in the cadets was mandatory for upper-level male students. ${ }^{101}$ Johnston also notes this in his study of the role of children in the Second World War. Gradually, cadets became, notwithstanding the concerns of the Toronto Board of Education among others, a seamless part of adolescence, particularly for boys.

Although at the outset cadet service was generally voluntary, it was, over the protests of some school officials and community groups, made obligatory for students in the upper grades of Toronto high schools in 1939. During the first year of the war, over 4,000 city students participated in cadet training, most of them aged between fifteen and seventeen years, the threshold of military age. Then, in the fateful summer of 1940, the program was abruptly broadened as bad news flooded in from the battlefronts in France. The number of students enrolled in Toronto doubled in the academic year 1940-41, with an almost 100 per cent turnout from the ranks of boys in grades ten to thirteen. By fall 1941, much to the gratification of local militia units, high school cadet corps were allowed to affiliate with such units, provided they were not required to drill regularly. ${ }^{102}$

Requests were also made to consider air and army cadet training as part of school curriculum. ${ }^{103}$ Special dispensation was also sought by the armed forces from the Toronto Board of Education's Regulation No. 8, which prohibited day students from participating in organizations using school gymnasiums in the evening. In this case, it was the Air Cadets that again sought to alter the existing board regulations. ${ }^{104}$ The motion to approve a dispensation was passed at the November 5, 1942 board meeting. ${ }^{105}$

Millar and Keshen note that the transition from childhood to the cadet corps was couched in the added responsibilities that children were to take on during the war. ${ }^{106}$ Childhood was to be accelerated and quickly resolved into early adulthood accompanied by additional serious burdens. Cadet Leagues were present in schools across Canada, including those in Toronto. ${ }^{107}$ The formation of army cadet corps in all the technical schools across the city was recommended in the "Advisory Vocational Committee Report" presented to the Toronto Board of Education on Wednesday, January 14, 1943. ${ }^{108}$ Johnston discusses the role of cadets in Central Technical School, highlighting the closeness of the military and the trades:

Service in the cadets, which on Ottawa's orders finally became compulsory in the manpower crisis of 1944, had not been confined to army training. Early on those boys captivated by the glamour of the air force had their wishes fulfilled when branches of the Air Cadet League of Canada were established in the province's high schools. Toronto was quick to respond and speedily planned for an aircraft instruction building at Central Technical School. So rapid was the expansion of the air cadet movement at some institutions in the city that it spilled over into special portables at nearby schools whose needs were not so pressing. ${ }^{109}$

Finally, Edwards describes the role that technical schools, notably Central Technical 
School, played in educating new recruits to the army: "Soldiers who display special aptitude, or who are particularly fitted because of previous experience, for one of the many skilled occupations modern mechanized warfare demands of its battalions, take their courses at schools such as Central Tech." 110 Clearly, the link between technical education and eventual participation in the war became more established as the war continued.

The last group considered here is adult labourers, both men and women. War was seen as an opportunity by many adults to get a better, more stable job and a better future. For the majority, the conduit through which they obtained that job was the short course in technical education for wartime industry. Labbé notes that industrial corporations were deeply involved in assessing and requisitioning specific types of workers. He refers to the General Engineering Company (GECO), a bomb and munitions factory in Scarborough, Ontario. ${ }^{111}$ GECO had a direct connection with Danforth Technical School and was able to get permission to establish emergency training programs by the middle of the war, 1943, to meet shortages of workers. ${ }^{112}$

Women's roles in the wartime technical education and industry are interesting to examine as well, and there is a widening field of research in this area. ${ }^{113}$ Amber Lloydlangston notes that women aspired to many different roles in wartime. Some had less educational background, while others aspired to more challenging positions, such as work as chemistry laboratory technicians. ${ }^{114}$ As Bloomfield notes as well, the connection between women's role in the war, technical education, and in industrial manufacturing for the war is well established: "Edith, for example went straight to the assembly line as a riveter after a few weeks of training at Central Technical School." 115 Women labourers were very much in demand, particularly after 1942, as Pierson documents. ${ }^{116} \mathrm{Up}$ until this point Canadian industry was still reabsorbing labourers laid off during the Depression of the 1930s. ${ }^{117}$ The other issue that became more and more prevalent as the war continued into 1943 was that women were leaving other low-paying jobs to compete for jobs in the war industries and manufacturing. ${ }^{118}$ Women were in demand for all kinds of jobs in a variety of wartime industries.

Specific provisions were put into place so that women could attend short courses at technical schools. With the inauguration of the War Emergency Training Program in 1940 , as noted earlier in this paper, technical schools in Toronto and elsewhere operated on a twenty-four-hour basis. Three shifts went from 8:15 am to $3 \mathrm{pm}$; from 3:30 pm to 11:20 pm, and from 11:30 pm to 7:30 am. ${ }^{119}$ As Edwards notes, often the trainees who went to emergency evening and night courses expected to be working in the daytime for their evening instructor in a particular industry. Women were restricted to taking the courses in the evening. ${ }^{120}$ They did not take courses that ran during the midnight shift. In a Maclean's article, Edwards, in a more patronizing tone, listed the industrial positions that he thought women were particularly suited for:

About six hundred of the 1,135 emergency war trainees registered at Central Tech last January were taking industrial training courses. Average length of these is from ten to twelve weeks, but some highly technical subjects take longer ... Women are particularly suited for certain operations. Meter assembly, for 
example, requires the accurate weaving of twenty-six strands of wire, each wrapped in a different colored covering. No men need apply here. The male sex, it seems, is affected with color blindness to a much greater degree than are women. ${ }^{121}$

Women were very quickly integrated into industry. Linda Wigley worked at Small Arms Limited in Long Branch, Ontario during the war. This factory was established at the beginning of the war and was instrumental in the production of the LeeEnfield rifle and the Sten machine carbine. ${ }^{122}$ Wigley went through a two-week training course at Central Technical School; her culminating graduation project was a machined hammer. ${ }^{123}$ What started as a two-week course stretched into a job that lasted most of the war, as she recorded:

Working at Small Arms Lmtd. Stretched into 4.5 years of a 3-shift workload. Day, afternoon and midnight (graveyard). A bonus system prevailed so all worked closely together. I ended my tenure working the A.I.D. Department (Inspection) ... ${ }^{124}$

One interesting detail here is that even though she was prohibited from attending midnight classes at school, she later worked the midnight shift in industry. ${ }^{125}$ In late September 1942, the Toronto Board of Education Advisory Vocation Committee reported and recommended:

[t]hat the Dominion-Provincial War Emergency Programme be granted evening use of one machine shop in each technical school, to train in war work men and women who are engaged in non-essential industry, the Programme authorities to pay all expenses involved as outlined in a communication from the Regional Director, dated September $10^{\text {th }}, 1942 .{ }^{126}$

Students, cadets, and women were all drawn towards war in a variety of ways, whether through patriotic curricula, technical subjects related to wartime technologies, the close connections between institutions of education and the cadet corps, and lastly, the promise of a higher paying job on the home front.

\section{Conclusions}

The Second War World mobilized many Western societies onto a wartime footing, including Canada, and the war extended into Canadian schools. This paper has critically examined this period, with a special focus on technical education, its place in secondary schools in the Toronto School Board, and in particular Central Technical School. In answering the questions raised in this article, a variety of issues emerged. Certainly, it is clear that the Second World War enhanced links between the military and education systems in the City of Toronto. The Canadian Army and Air Force became a much greater presence in the city during the war. The Stanley Barracks on 
the Canadian National Exhibition grounds is one significant example of this. Within the school system, the increasing integration of the Toronto Board of Education and the Canadian military forces is made clear in the historical documents. Military training became, in part, the mission of the school. Moreover, changes can also be seen in the school calendar and the curriculum. Not only were schools running twentyfour hours a day, but the curriculum taught there was amended to appeal to several distinct clienteles during the war. "Normal" students were taught during the day; in the evening, Army, Navy, and Air Force cadets corps prevailed; and throughout the evening and on into the night, ad hoc night schools taught men and women the skills they needed to work in wartime industries. Curriculum goals also changed, reflecting the prevailing patriotism and concurrently moving away from student-centred learning towards a teacher-as-leader approach. Curriculum also became more popular with some students because it furthered their aim of entering a career in the armed forces, for example, in aerospace technology. Explaining the pull towards the military and service in wartime industries is a more complex question, and many different factors came into play in assessing this. Patriotism and related propaganda were key elements in the transition between elementary to secondary school technical education and military service. The desire to work with some of the most technologically advanced machinery of the day also played a role - the lure of advanced fighter aircraft like the Hawker Hurricane and the Spitfire pushed aside all other considerations for some boys. Finally, upon graduating, for some the question "what now?" played a role: taking the next step into a military career was seen as the logical conclusion for some students once their schooling was complete.

This paper has identified some of the effects of war on technical education in Toronto. More research in terms of the exact numbers of students engaged in technical education province-wide, their preferences, and their eventual career choices would be helpful in understanding this area of historical study. One of the legacies of technical education in wartime is to show that schools can be surprisingly versatile in their function. Today, when technical shops are often closed and dark in the evening, it is interesting to know that during wartime, they moved to an altogether different rhythm.

\section{Notes}

1 Central Technical School was established in 1891 as the Toronto Technical School. It is still in operation today.

2 Dustin Garnet, "Unknown and Hidden: The Toronto District School Board Education Archive," Canadian Review of Art Education: Research \& Issues 39 (2012): 48.

3 City of Toronto Archives, "Toronto Archives - Your City - Living in Toronto I City of Toronto," City of Toronto, http://www1.toronto.ca/wps/portal/contentonly?vgnextoid= 7cb4ba2ae8b1e310VgnVCM10000071d60f89RCRD, accessed on October 27, 2014.

4 Scott documents the important contributions of First Nations in Canada's Second World War effort. Scott Sheffield, "Fighting a White Man's War? First Nations Participation in the Canadian War Effort, 1939-1945," in Canada and the Second World War: Essays in Honour of Terry Copp, ed. Geoffrey Hayes, Michael Bechthold, and 
Matthew Symes (Waterloo: Wilfrid Laurier University Press, 2012), 67; R. S. Sheffield, The Red Man's on the Warpath: The Image of the "Indian" and the Second World War (Vancouver: UBC Press, 2013).

5 This is an area where further research is needed. Caccia looks at adult education and citizenship during the war, but there is little coverage elsewhere. See, Ivana Caccia, "Managing the Canadian Mosaic: Dealing with Cultural Diversity During the WWII Years" (Ph.D. thesis, University of Ottawa, 2006), 189.

6 There are several authors that look at the more political side of educational change during the war. Christou touches on this in the seventh chapter of his recent book, while looking more fully at the issue of progressive education. Patterson also looks at this in his chapter in Canadian Education: A History. Also, and more recently, Millar gives a brief overview in her web-based resource. See T. M. Christou, Progressive Education: Revisioning and Reframing Ontario's Public Schools, 1919-1942 (Toronto: University of Toronto Press, 2012), 132-38, passim; Robert Patterson, "Society and Education during the Wars and Their Interlude: 1914-1945," in Canadian Education: A History, ed. Donald Wilson, Louis-Phillipe Audet, and Robert Stamp (Scarborough: Prentice-Hall, 1970), 360-384; Anne Millar, "Education during the Second World War," Wartime Canada Website, http://wartimecanada.ca/essay/learning/educationduring-second-world-war, accessed on July 10, 2014.

7 Harold D. Lasswell, "The Garrison State," American Journal of Sociology (1941): 455.

8 R. B. Bryce and M. J. Bellamy, Canada and the Cost of World War II: The International Operations of Canada's Department of Finance, 1939-1947 (Montreal and Kingston: McGill-Queen's University Press, 2005), 22-23.

9 S. Durflinger, Fighting from Home: The Second World War in Verdun, Quebec (Vancouver: UBC Press, 2011), 3-6.

10 Mark Harrison, "Why the Rich Won: Economic Mobilization and Economic Development in Two World Wars" (Working paper, University of Warwick, 2005), 6.

11 Daniel Byers, "Mobilising Canada: The National Resources Mobilization Act, the Department of National Defence, and Compulsory Military Service in Canada, 19401945," Journal of the Canadian Historical Association/Revue de la Société historique du Canada 7, no. 1 (1996): 180.

12 Robert Bothwell, " 'Who's Paying for Anything These Days?' War Production in Canada 1939-1945," in Mobilization for Total War: The Canadian, American and British Experience 1914-1918, 1939-1945, ed. N. Dreisziger (Waterloo: Wilfrid Laurier University Press, 1981), 61.

13 For Prime Minister Mackenzie King, this proved to be the most challenging and feared task. See T. Cook, Warlords: Borden, Mackenzie King and Canada's World Wars (Don Mills: Penguin Canada, 2012), 223.

14 M. D. Stevenson, Canada's Greatest Wartime Muddle: National Selective Service and the Mobilization of Human Resources During World War II (Montreal and Kingston: McGillQueen's University Press, 2001), 12.

15 Ian R. Dowbiggin, "Seath, John," Dictionary of Canadian Biography, Volume 14, University of Toronto/Université Laval, http://www.biographi.ca/en/bio/seath_john_14E.html, accessed on December 2, 2015.

16 D. Glendenning, "Impact of Federal Financial Support on Vocational Education in Canada" (Ph.D. thesis, Indiana University, 1964), 3. See also John Squair, John Seath and the School System of Ontario (Toronto: University of Toronto Press, 1920), 105.

17 Indeed, Seath worked at a time when interest in technical education was close to its zenith in Canada. See Seath's report: John Seath, Education for Industrial Purposes (Toronto: L. K. Cameron, 1911); and Harry Smaller, "Vocational Education in Ontario's Secondary Schools: Past, Present - and Future?," in Integrating School and Workplace Learning in Canada: Principles and Practices of Alternation Education and 
Training, ed. Hans G. Schütze and Robert Sweet (Montreal and Kingston: McGillQueen's University Press, 2003), 12-13.

18 Anthony Turco, "Federal Incursions into Education: Willing Participant or Reluctant Partner?” (M.Ed. thesis, Nipissing University, 2006), 10.

19 George Buck, "Technical Education," The Canadian Encyclopedia, http://www. thecanadianencyclopedia.ca/en/article/technical-education/, accessed on December 2, 2015.

20 Glendenning, "Impact of Federal Financial Support on Vocational Education," 19.

21 Government of Canada, "The Technical Education Act in Operation," Government of Canada, http://socserv.mcmaster.ca/oldlabourstudies/onlinelearning/article.php?id=738, accessed on December 18, 2015.

22 A. J. Peters, "The Changing Idea of Technical Education," British Journal of Educational Studies 11, no. 2 (1963): 145.

23 Ibid.

24 Ibid., 153.

25 Ibid., 154.

26 Gary McCulloch, "Policy, Politics and Education: The Technical and Vocational Education Initiative," Journal of Education Policy 1, no.1 (1986): 35-52. Steve Jordan, "The Technical Vocational Education Initiative (TVEI) and the Making of the Enterprise Culture" (Ph.D. thesis, McGill University, 1996).

27 Very early on, it was connected to the question of mechanics institutes.

28 Rosa Bruno-Jofré, "History of Education in Canada: Historiographic 'Turns' and Widening Horizons," Paedagogica Historica 50, no. 6 (2014): 774-785. Bruno-Jofré does not mention it in her most recent article, while Axelrod's 1996 coverage of this area is better; he acknowledges technical education in conjunction with other themes (i.e., women's education, reproduction of class, modernization) in the historiography of the history of education in Canada. See Paul Axelrod, "Historical Writing and Canadian Education from the 1970s to the 1990s," History of Education Quarterly (1996): 33. Axelrod also covers it briefly in his 1997 book. See Paul Axelrod, The Promise of Schooling: Education in Canada, 1800-1914 (Toronto: University of Toronto Press, 1997), 107-13.

29 Suzanne Zeller, "Roads Not Taken: Victorian Science, Technical Education, and Canadian Schools, 1844-1913," Historical Studies in Education/Revue d'histoire de l'éducation 12, no. 1 (2000): 1-28. Robert M. Stamp, "The Campaign for Technical Education in Ontario, 1876-1914" (Ph.D. thesis, University of Western Ontario, 1970); Robert Gidney and Wyn Millar, Inventing Secondary Education: The Rise of the High School in Nineteenth-Century Ontario (Montreal and Kingston: McGill-Queen's University Press, 1990).

30 Zeller, "Roads Not Taken," 1.

31 Ibid.

32 Ibid.

33 B. Curtis et al., Stacking the Deck: The Streaming of Working-Class Kids in Ontario Schools (Toronto: James Lorimer Limited, 1992), 39.

34 Gidney and Millar, Inventing Secondary Education, 286.

35 Ibid., 289.

36 Alison Taylor, "The Contradictory Location of High School Apprenticeship in Canada," Journal of Education Policy 25, no. 4 (2010): 505.

37 John E. Lyons et al., "The Development of Vocational Education in Canada," Canadian Journal of Education/Revue canadienne de l'education (1991): 137-150.

38 Ibid., J. Donald Wilson, "The Ryerson Years in Canada West," in Canadian Education: A History, ed. J. Donald Wilson, Robert Stamp, and Louis-Philippe Audet (Scarborough: Prentice-Hall, 1970). 
39 Lyons et al., "The Development of Vocational Education in Canada"; Gidney and Millar, Inventing Secondary Education.

40 Robert M. Stamp, "Technical Education, the National Policy, and Federal-Provincial Relations in Canadian Education, 1899-1919," Canadian Historical Review 52, no. 4 (1971): 404-423.

41 Ibid.

42 Lyons et al., "The Development of Vocational Education in Canada."

43 Stamp, "Technical Education, the National Policy, and Federal-Provincial Relations."

44 J. A. McIntyre, "Hugh Guthrie of Guelph (1866-1939)," International Review of Scottish Studies 12 (2008): 142.

45 As Dowbiggin highlights, Stamp argues that this act was passed during a time of great social unrest. See I. R. Dowbiggin, "The Origins of Technical Education in London: Context, Concerns and Curriculum, 1910-1915," in Through the Schoolhouse Door: Working Papers, ed. I. Goodson and C. J. Anstead (Boston: Sense Publishers, 2010), 34, and Stamp, "Technical Education, the National Policy, and Federal-Provincial Relations"; Royal Commission on Industrial Training, Royal Commission on Industrial Training and Technical Education: Report of the Commissioners (Ottawa: C. H. Parmelee, 1913).

46 Recently on CBC television, a documentary was broadcast that compared technical education in Canada and Switzerland. See Sharon Bartlett et al., "Generation Jobless," broadcast on Doc Zone, CBC Television, 2014, http://www.cbc.ca/doczone/episodes/generation-jobless, accessed on March 3, 2015.

47 Kathleen Yolande Sharman, "The Origins and the Significance of the Toronto Technical School, 1891-1904," Journal of Technical Education and Training 3, no. 1 (2011): 1-12.

48 Ibid.

49 Ibid.

50 Kathleen Yolande Sharman and Larry A. Glassford, "The Appeal of Technical Education in Tough Times: A Comparison of the Toronto and Windsor Experiences, 1890-1930," Historical Studies in Education/Revue d'histoire de l'education 23, no. 2 (2011): 54. Kael Sharman addresses technical education and the Windsor-Walkerville Technical School; see Kael Rodrique Sharman, "Gender, Class and Curriculum at W. D. Lowe Technical Secondary School, 1923-1973: A Study in Continuity and Change" (Ph.D. thesis, University of Windsor, 2014).

51 See Ivor F. Goodson and I. R. Dowbiggin, "Vocational Education and School Reform: The Case of the London (Canada) Technical School, 1900-1930," History of Education Review 20, no. 1 (1991): 39-60.

52 Robert M. Stamp, “Canadian High Schools in the 1920's and 1930's: The Social Challenge to the Academic Tradition," Historical Papers/Communications historiques 13, no. 1 (1978): 82.

53 Ian Radforth and Joan Sangster, "'A Link Between Labour and Learning': The Workers Educational Association in Ontario, 1917-1951," Labour/Le Travail (1981): 50.

54 Smaller, "Vocational Education in Ontario's Secondary Schools," 6; L. S. Beattie and the Metropolitan Toronto School Board Special Committee on Technical Education in Metropolitan Toronto, Special Report on the Extension of Technical Education in Metropolitan Toronto (Toronto: Metropolitan School Board, 1959).

55 I. R. Dowbiggin, "F. W. Merchant and Technical Classes in London," in Through the Schoolhouse Door, ed. Goodson and Anstead, 47.

56 Rebecca Priegert Coulter, "Schooling Work \& Life: Reflections of the Young in the 1940s," in Rethinking Vocationalism: Whose Work/Life is It?, ed. R. P. Coulter and I. F. Goodson (Toronto: James Lorimer Limited, 1993), 71.

57 S. S. Freeman, "The Intersection of Policy and Practice in One Stand-alone Vocational School: The ABC Story" (Ph.D. thesis, University of Toronto, 2006), 6-9. 
58 Albert Hodgins, "Minutes of the Board of Education, 1939, Year of the Royal Visit," ed. Toronto Board of Education Chief Accountant (Toronto: Toronto Board of Education, 1939), 124.

59 Ibid., 141.

60 Ibid., 142.

61 Ian Miller, "Toronto's Response to the Outbreak of War, 1939," Canadian Military History 11, no. 1 (2002): 5-23.

62 K. H. Frieser, The Blitzkrieg Legend (Annapolis: Naval Institute Press, 2013), 33.

63 Lyons et al., "The Development of Vocational Education in Canada."

64 Liwen Chen, "Small Arms, Ltd. 1940-1946” (Mississauga: Heritage Mississauga, 2003).

65 A. Sendzikas, Stanley Barracks: Toronto's Military Legacy (Toronto: Dundurn, 2011), 129-139.

66 Matthew Evenden, "Lights Out: Conserving Electricity for War in the Canadian City, 1939-1945," Revue d'histoire urbaine/Urban History Review 34, no. 1 (2005): 88.

67 Ibid.

68 Gerald T. Bloomfield, "Working for the War Effort: Women and Manufacturing Industry in Ontario, 1939-1945,” The Great Lakes Geographer 4, no. 1 (1997): 69.

69 Howard Fluxgold, "Federal Financial Support for Secondary Education and Its Effect on Ontario, 1900-1972" (Toronto: Ontario Teachers' Federation, 1972), 67.

70 Ibid.

71 Laurel Sefton MacDowell, "The Formation of the Canadian Industrial Relations System During World War Two," Labour/Le Travail (1978): 179.

72 Fluxgold, "Federal Financial Support for Secondary Education," 67-68.

73 Ibid., 77.

74 Central Technical School, "Central Technical School—A School History,” http:// schools.tdsb.on.ca/centraltech/aboutus/history.php, accessed on June 19, 2014.

75 Panayotidis talks about Central Technical School in the context of the arts in this era. One of the key issues that arose was the question of whether teachers were able to take on extra work outside of school hours. See Euthalia Lisa Panayotidis, "The Bureaucratization of Creativity, the British Arts and Crafts Movement and its Impact on Ontario Education, 1880-1940" (Ph.D. thesis, University of Toronto, 1997), 27.

76 Christou, Progressive Education, 680.

77 Ibid.; Patterson, "Society and Education during the Wars and Their Interlude."

78 J. A. Keshen, Saints, Sinners, and Soldiers: Canada's Second World War (Vancouver: UBC Press, 2007), 219.

79 Central Technical School, "The Vulcan, 1891-1941. Golden Jubilee: 50 Years of Technical Education," in Larry Becker Fonds: Fonds 70; Series 600; Larry Becker Education, Subseries 3; Primary and secondary schools, ed. Central Technical School (Toronto: City of Toronto Archives, 1941), 48.

80 Anne Millar and Jeff Keshen, "Rallying Young Canada to the Cause: Anglophone Schoolchildren in Montreal and Toronto During the Two World Wars," History of Intellectual Culture 9, no. 1 (2010): 10.

81 Ibid.

82 Ibid., 15.

83 S. Durflinger, Fighting from Home: The Second World War in Verdun, Quebec (Vancouver: UBC Press, 2011), 124.

84 Keshen, Saints, Sinners, and Soldiers, 202.

85 Toronto Board of Education, "Calendar of the Technical Schools," ed. Toronto Board of Education (Toronto: Toronto District School Board Archives, 1945); Central Technical School, "The Vulcan, 1891-1941," passim.

86 Toronto Board of Education, "Calendar of the Technical Schools," passim. 
87 Kristina Llewellyn, Democracy's Angels: The Work of Women Teachers (Montreal and Kingston: McGill Queen's University Press, 2012), 128.

88 Central Technical School, "The Vulcan, 1891-1941," 33.

89 Ibid., 29.

90 Douglas H. Crawford, "School Mathematics in Ontario 1894-1959: Expansion and Moderate Reform," in A History of Mathematics Education in the United States and Canada, ed. National Council of Teachers of Mathematics (Washington, DC: National Council of Teachers of Mathematics, 1970), 399; A. Karp and G. Schubring, Handbook on the History of Mathematics Education (New York: Springer, 2014), 330.

91 Matthew Chapman, "The Evolution of Professional Aviation Culture in Canada, 19391945” (M.A. thesis, University of Victoria, 2010).

92 Geoffrey Hayes, "Science and the Magic Eye: Innovations in the Selection of Canadian Army Officers, 1939-1945," Armed Forces \& Society 22, no. 2 (1995): 276; Geoffrey W. Hayes, "The Development of the Canadian Army Officer Corps, 1939-1945" (Ph.D. thesis, University of Western Ontario, 1992).

93 Keshen, Saints, Sinners, and Soldiers, 202.

94 Coulter speaks of the stronger draw of war work compared to to high school completion for adolescents. See Coulter, "Schooling Work \& Life," 70.

95 Charles M. Johnston, "The Children's War: The Mobilization of Ontario Youth during the Second World War," in Patterns of the Past: Interpreting Ontario's History, ed. Roger Hall, William Westfall, and Laurel Sefton MacDowell (Toronto: Dundurn Press, 1988), 365.

96 Frederick Edwards, “Night and Day School,” MacLean’s, May 1, 1942: 75.

97 Johnston, "The Children's War," 371.

98 Coulter also draws our attention to the fact that some adults were concerned that the war and the pressure to be involved in "war work" and cadets was leading adolescents into "blind alley occupations." See Coulter, "Schooling Work \& Life," 71.

99 Mark Moss, Manliness and Militarism: Educating Young Boys in Ontario for War (Toronto: University of Toronto Press, 2001); Tamara Myers and Mary Anne Poutanen, "Cadets, Curfews, and Compulsory Schooling: Mobilizing Anglophone Children in WWII Quebec,” Histoire sociale/Social History 38, no. 76 (2005): 367-398. See also I. Goodson and C. J. Anstead, "Structure and Mediation: Glimpses of Everyday Life at London Technical and Commercial High School, 1920-1940," in Through the Schoolhouse Door, 124.

100 Moss, Manliness and Militarism.

101 Government of Ontario and Department of Education, "Report of the Minister of Education, Province of Ontario for the Year 1944," ed. Department of Education (Toronto: T. E. Bowman, 1946); Millar, "Education during the Second World War"; Millar and Keshen, "Rallying Young Canada to the Cause," 10.

102 Johnston, "The Children's War," 369-370.

103 Albert Hodgins, "Minutes of the Board of Education, 1941," ed. Toronto Board of Education Chief Accountant (Toronto: Toronto Board of Education, 1941), 148.

104 Albert Hodgins, "Minutes of the Board of Education, 1942," ed. Toronto Board of Education Chief Accountant (Toronto: Toronto Board of Education, 1942), 168.

105 Ibid., 172-173.

106 Millar and Keshen, "Rallying Young Canada to the Cause," 10.

107 Millar, "Education during the Second World War."

108 Albert Hodgins, "Minutes of the Board of Education, 1943," ed. Toronto Board of Education Chief Accountant (Toronto: Toronto Board of Education, 1943), 7-9.

109 Johnston, "The Children's War," 370.

110 Edwards, "Night and Day School." 
111 Pierrick Labbé, "La gestion des ressources humaines dans les usines de munitions durant la Deuxième Guerre mondiale: le cas de la General Engineering Company," Labour/Le Travail 65 (2010): 110.

112 Ibid., 123.

113 One of the first historians to look at this was Ruby Heap. See Ruby Heap, "Schooling Women for Home or for Work? - Vocational Education for Women in Ontario in the Early Twentieth Century: The Case of the Toronto Technical High School, 18921920," in Gender and Education in Ontario: An Historical Reader (Toronto: Canadian Scholars' Press, 1991), 195-243.

114 Amber Lloydlangston, "Applying to Be 'Industrial Soldiers': The Letters of Young Women Wanting to Train as Chemistry Laboratory Technicians, 1942-1944," Historical Studies in Education/Revue d'histoire de l'éducation 26, no. 2 (2014): 31.

115 Bloomfield, "Working for the War Effort," 82.

116 Ruth Pierson, "Women's Emancipation and the Recruitment of Women into the Canadian Labour Force in World War II," Société historique du Canada, Communications historiques (1976): 155.

117 Ibid., 142.

118 Ibid., 145.

119 Edwards, "Night and Day School."

120 Ibid.

121 Ibid.

122 Chen, "Small Arms, Ltd. 1940-1946," 3.

123 This hammer forms part of the Linda Wigley Collection at the City of Toronto Archives. It comes with the following framed statement: "When world war two broke out so many men were in the services that the government brought in women from across the country to work in the war plants springing up in and around T.O. These women were billeted in hastily built barracks or in private homes. This in turn gave our mothers the opportunity of leaving the home for a few hours to work in the cafeterias. To prepare women to enter the plants a two-week training course was set up at T.O's Central Technical School in their machine shop. In 1941 as a young 18-year-old girl, I was one of the thousands of women who graduated from the course and then spent the next 4.5 years working at a plant making the Lee Enfield rifle. The attached steel hammer was the required tool for graduating and 'Hammer' and I have not been separated until now: 1988. (Please handle with care) Mrs. Linda Wigley.” Linda Wigley, "Linda Wigley Framed Statement," in Linda Wigley Collection: Fonds 1630 (Toronto: City of Toronto Archives, 1987).

124 Linda Wigley, "Linda Wigley Coverpage," in Linda Wigley Collection: Fonds 1630 (Toronto: City of Toronto Archives, 1987).

125 This bears further investigation. Another future avenue of research could be to compare the restrictions placed on women at CTS and the lack of restrictions on women in industry.

126 Hodgins, "Minutes of the Board of Education, 1942," 322. 